\title{
A HENGERES FOGASKERÉK-LEFEJTŐ CSIGAMARÓ MÛKKÖDŐ ÉLGEOMETRIÁJÁNAK VIZSGÁLATA
}

\section{THE ACTIVE GEOEMTRY OF THE HOBBING CUTTERS USED FOR CYLINDRICAL GEAR MANUFACTURING}

\author{
Máté Márton ${ }^{1}$, Hollanda Dénes ${ }^{2}$ \\ ${ }^{1}$ Sapientia Erdélyi Magyar Tudományegyetem, Marosvásárhelyi Kar, Gépészmérnö- \\ ki Tanszék, 540485 Marosvásárhely, O.p.9, C.P 4, Telefon / Fax: +40-265-206210/ \\ +40-265-206211,mmate@ms.sapientia.ro \\ ${ }^{2}$ Sapientia Erdélyi Magyar Tudományegyetem, Marosvásárhelyi Kar, Gépészmérnö- \\ ki Tanszék, 540485 Marosvásárhely, O.p.9, C.P 4, Telefon / Fax: +40-265-206210 / \\ +40-265-206211,hollanda@ms.sapientia.ro
}

\begin{abstract}
During the cutting the gear hob executes a complex relative motion related to the machined gear. Thus the study of the cutting geometry cannot be done using the classic methods of the synthetic geometry. This paper shows the computing model of the functional cutting geometry without approximations. The model admits that the cutting edge results as the intersection of a perfect involute worm and a helical rake face whose generatrix is perpendicular and intersects the axis of the worm. The relief face is meshed by the cutting edge while it moves along a conical helix leading curve respecting the motion law of the relieving operation. Using the analytical expressions of the cutting edge and its delimiting surfaces the normal vectors and the relative velocity vector will be computed in the considered edgepoint. Using these, the functional rake and relief angle values are computed. It is also proved that the repartitions of the rake and relief angles depend on the position of the edgepoint related to the machined gear and the geometrical peculiarities of this.
\end{abstract}

Keywords: gear-hob, rake angle, relief angle, functional cutting geometry

\section{Összefoglalás}

A csigamaró a megmunkált fogaskerékhez képest összetett, bonyolult relatív mozgást ír le. A müködő élgeometria tanulmányozása emiatt klasszikus geometriai módszerekkel nem lehetséges. Jelen dolgozat a közelítés nélküli müködő élgeometria számítási modelljét ismerteti részleteiben. A számítás az elméletileg tökéletes evolvens csigából származtatott csigamaró élére és fogfelületeire alapoz. Kiinduló feltételként elfogadjuk, hogy a homlokfelület a csiga tengelyét metsző, erre merőleges egyenes által leírt csavarvonal-felület. A hátfelületet a tökéletes él-alkotógörbe generálja azáltal, hogy a csavarvonal szerinti hátraesztergálás kúpos csavarvonal-vezérgörbéjén, a hátramunkálás kinematikai törvényei szerint elmozdul. A homlok- és a hátfelületek, valamint az él analitikus alakját felhasználva felírjuk a tetszőleges élpontban definiált érintő-, felületi normális- és relatív sebességvektorokat, majd ezek segítségével kiszámítjuk a müködő homlok- és hátszögértékeket. Kimutatjuk, hogy a müködö élszögek eloszlása az élpontnak a megmunkált fogaskerékhez viszonyított helyzetétől, valamint ennek geometriai jellemzőitől függ.

Kulcsszavak: csigamaró, homlokszög, hátszög, müködö élgeometria 


\section{A csigamaró fogának analitikus modellje}

A csigamarót elméletileg úgy hozzuk létre, hogy az elméletileg pontos (virtuális burkoló) evolvens csiga felületeit elmetszszük $z_{m}$ számú, egyenletes kiosztású homlok-csavarfelülettel, majd pedig az ily módon kapott élgörbéket a hátramunkálásnak megfelelő kúpos csavarvonalakon mozdítjuk el $[1,3,4]$. A geometriai modell előállí- tásában, ennek megfelelően, a következő lépéseket hajtjuk végre:

- az evolvensgörbe egyenleteinek felírása a homlokszelvényben;

- az evolvens csavarfelületek felírása;

-a homlokfelület implicit egyenletének felírása;

- az élgörbék egyenleteinek elóállítása;

- az élgörbék elmozdítása a csavarirányú hátramunkálás mozgástörvénye szerint.

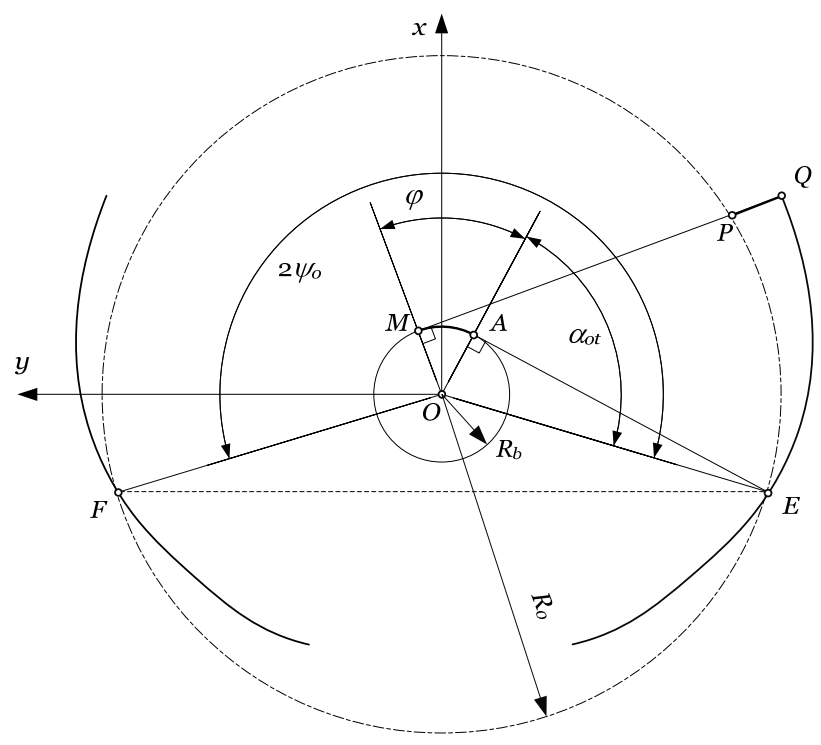

1. ábra. A csiga fogának generáló evolvens ivei

Az evolvensgörbe egyenleteit nem a hagyományos módon [1, 6, 7] írjuk fel, mivel az alapkör sugara sokkal kisebb, mint a müködési határkörök (fejkör, lábkör) sugarai, így a paraméter értéke nehezen értelmezhetö; ehelyett az osztókörre irányítjuk a paraméter nulla értékét. Az $E$ ponton áthaladó, a jobb oldali fogfelületet generáló evolvens egyenletei az 1. ábra alapján a következők [4]:

$$
\left\{\begin{array}{l}
x(\varphi)=R_{b}\left(\cos E_{1}(\varphi)+\left(\operatorname{tg} \alpha_{0 t}+\varphi\right) \sin E_{1}(\varphi)\right) \\
y(\varphi)=R_{b}\left(\sin E_{1}(\varphi)-\left(\operatorname{tg} \alpha_{0 t}+\varphi\right) \cos E_{1}(\varphi)\right)
\end{array}\right.
$$

Az $E$, illetve az $F$ osztóköri pontok a $2 \psi_{0}$ központi szögértékkel jellemzett osztóköri íven mért fogvastagságot határozzák meg. Figyelembe véve, hogy a csigamarót származtató evolvens csiga $\frac{\pi}{2}-\lambda_{0}$ fogferdeségü fogaskerék, az osztóköri ívhosszt az ismert 


$$
s_{0 t}=\frac{\pi}{2} m_{t}+2 m_{t} \xi_{t} \operatorname{tg} \alpha_{0 t}
$$

képlettel számítjuk ki. Nulla profileltolás esetében $\psi_{0}=\frac{\pi}{2}$. Az (1) egyenletekben szereplő szögargumetum értéke az 1. ábra alapján

$$
E_{1}(\varphi)=-\psi_{0}+\alpha_{0 t}+\varphi
$$

Az $F$ ponton áthaladó, a bal oldali fogfelületet generáló evolvens egyenleteit, az Oy tengelyre való szimmetria alapján, az (1) képletböl generáljuk, úgy, hogy az $y$ koordináta-függvényt -1-gyel szorozzuk.

$\mathrm{Az}$ evolvens csiga fogfelületeit az $E$ és $F$ pontokon áthaladó evolvenseknek a megfelelö alaphengeri csavarvonalakon való elcsavarásával képezzük (2. ábra).

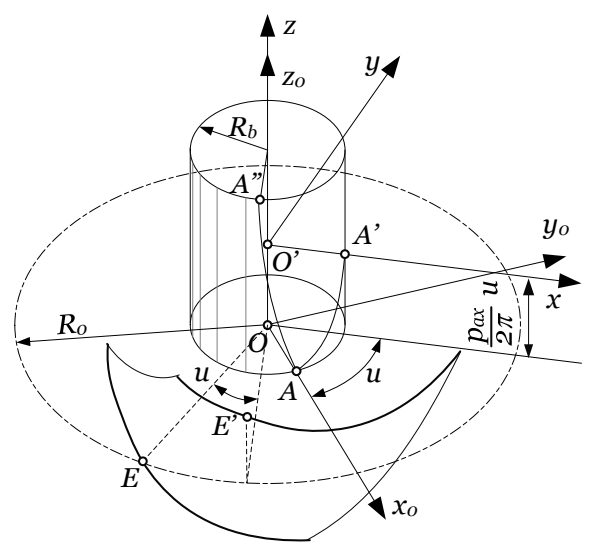

2. ábra. A csiga felületeinek és a homlokfelület generálása

A csavarmozgás transzformációs mátrixa

$$
M_{0}=\left(\begin{array}{cccc}
\cos u & -\sin u & 0 & 0 \\
\sin u & \cos u & 0 & 0 \\
0 & 0 & 1 & \frac{p_{a x}}{2 \pi} u \\
0 & 0 & 0 & 1
\end{array}\right)
$$

ezzel pedig a felületegyenletek mátrixos alakja a következő lesz:

$$
\underline{\mathbf{r}_{0}}(u, \varphi)=\mathbf{M}_{0} \underline{\mathbf{r}}(\varphi)
$$

A jobb és bal fogfelületek egyenleteit általánosított formában írjuk fel. Ehhez az $\underline{\mathbf{r}}(\varphi)$ oszlopban az $y$ koordinátafüggvényt a $j$ kapcsolóparaméterrel szorozzuk, ahol $j=-1$-re a bal oldal, míg +1-re a jobb oldal egyenleteit kapjuk. Bevezetjük az alábbi változócseréket:

$$
\begin{aligned}
& E_{1}(\varphi)=\varphi_{1}-\zeta=\left(\varphi+\operatorname{tg} \alpha_{0 t}\right)-\left(\psi_{0}+\operatorname{inv} \alpha_{0 t}\right) \\
& v_{1}=\varphi_{1}+j u
\end{aligned}
$$

Az (1), (3), (5) képletekkel végzett elemi számítások eredményeképpen a következő, általános fogoldalegyenleteket kapjuk:

$$
\left\{\begin{array}{l}
x_{0}\left(\varphi_{1}, v_{1}\right)=R_{b}\left(\cos \left(v_{1}-\zeta\right)+\varphi_{1} \sin \left(v_{1}-\zeta\right)\right) \\
y_{0}\left(\varphi_{1}, v_{1}\right)=j R_{b}\left(\sin \left(v_{1}-\zeta\right)-\varphi_{1} \cos \left(v_{1}-\zeta\right)\right) \\
z_{0}\left(\varphi_{1}, v_{1}\right)=j R_{b} \operatorname{tg} \lambda_{b}\left(v_{1}-\varphi_{1}\right)
\end{array}\right.
$$

A homlokfelület egyenleteit hasonló módon írjuk fel, figyelve arra, hogy ez bal sodrású, és osztóhengeri csavarvonala meröleges a fogoldalak osztóköri csavarvonalaira. A parametrikus formából a következő implicit egyenletet állítjuk elö:

$$
\frac{p_{C}}{2 \pi} \operatorname{arctg} \frac{y_{0}}{x_{0}}+z_{0}=0, p_{C}=\frac{p_{a x}}{\operatorname{tg}^{2} \lambda_{0}}
$$

$\mathrm{Az}$ oldalélek általános parametrikus egyenleteit a (6) és (7) egyenletekből kapjuk.

$$
\left\{\begin{array}{l}
x_{0}\left(\varphi_{1}\right)=R_{b}\left(\cos B\left(\varphi_{1}\right)+\varphi_{1} \sin B\left(\varphi_{1}\right)\right) \\
y_{0}\left(\varphi_{1}\right)=j R_{b}\left(\sin B\left(\varphi_{1}\right)-\varphi_{1} \cos B\left(\varphi_{1}\right)\right) \\
z_{0}\left(\varphi_{1}\right)=j \frac{p_{C} p_{a x}}{2 \pi\left(p_{C}+p_{a x}\right)}\left(\zeta+\operatorname{arctg} \varphi_{1}-\varphi_{1}\right) \\
B\left(\varphi_{1}\right)=\frac{p_{a x}\left(\varphi_{1}-\zeta\right)+p_{C} \operatorname{arctg} \varphi_{1}}{\left(p_{C}+p_{a x}\right)}
\end{array}\right.
$$


A hátfelületek egyenleteit a 3. ábra alapján levezetett koordináta-transzformáció segítségével írjuk fel. A hátfelületet ebben az esetben a (8) parametrikus egyenletekkel előállított élek kúpos csavarvona- lon való elmozdításával kapjuk. Meg kell jegyezni, hogy a köszörüléssel elöállított hátfelületek az elméletitől elhanyagolható módon eltérnek, ez azonban nem befolyásolja a geometria számításának pontosságát.

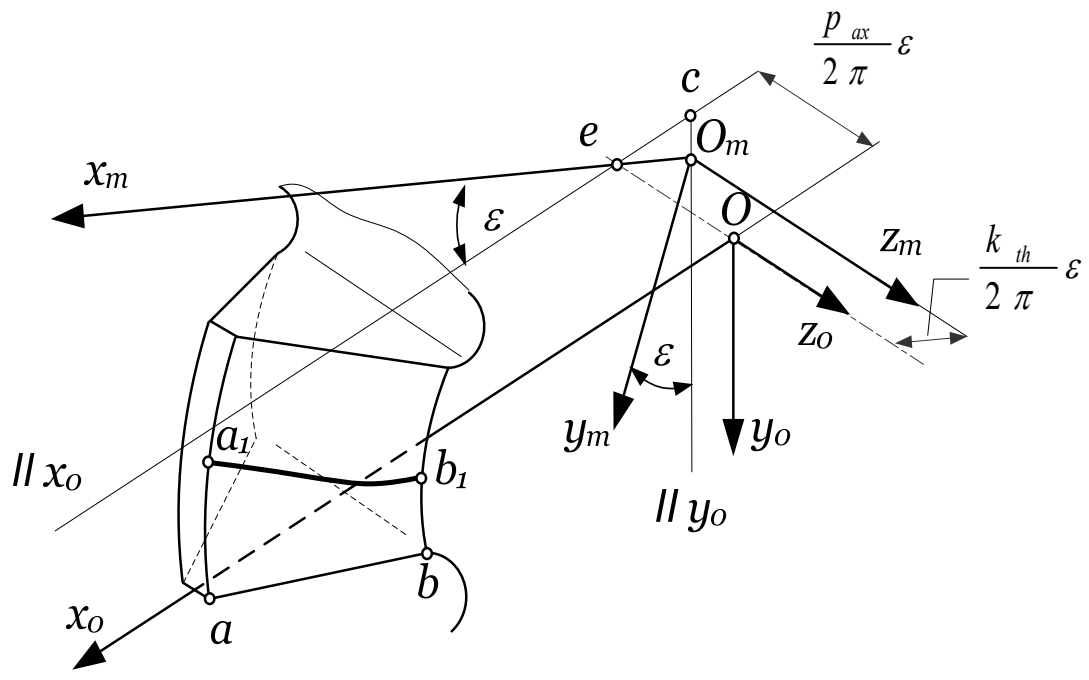

3. ábra. A csigamaró oldal-hátfelületeinek generálása csavarvonal szerinti hátramunkálással

Az éleket szállító $\left(x_{m} y_{m} z_{m}\right)$ koordinátarendszernek a szerszám $\left(x_{0} y_{0} z_{0}\right)$ rendszeréhez viszonyított elmozdulását az alábbi transzformációs mátrixszal írjuk le, ahol $a$ val az Arkhimédész-féle spirális paraméterét jelöltük:

$$
\mathbf{M}_{0 m}=\left(\begin{array}{cccc}
\cos \varepsilon & \sin \varepsilon & 0 & -a \varepsilon \cos \varepsilon \\
-\sin \varepsilon & \cos \varepsilon & 0 & a \varepsilon \sin \varepsilon \\
0 & 0 & 1 & -\frac{p_{a x}}{2 \pi} \varepsilon \\
0 & 0 & 0 & 1
\end{array}\right)
$$

Az élegyenleteket a

$$
\underline{\mathbf{r}_{0}}=\mathbf{M}_{0 m} \underline{\mathbf{r}_{m}}
$$

mátrixegyenletből kapjuk, ahol az $\underline{\mathbf{r}_{m}}$ homogén koordinátaoszlop elemei a (8) függvények. A $\lambda_{0}=2^{\circ} 30^{\prime}$ dölésszögü egyetlen bekezdésü csigamaróra elvégzett számítá- sok alapján elóállított fogfelületeket a 4 . ábrán szemléltettük.

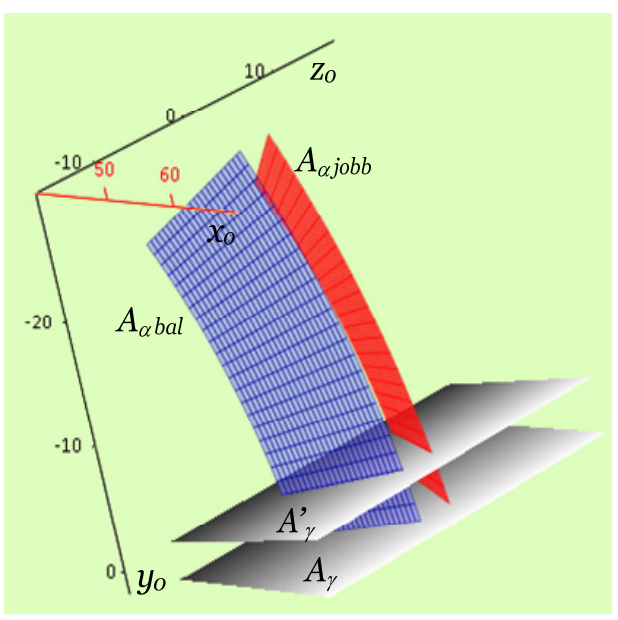

4. ábra. A csigamaró fogának felületei 


\section{A múködő élgeometria matema- tikai modellje}

A müködő élgeometriát az általános vektoriális számítási modell [4] csigamaróra való sajátosításából kapjuk. A müködő homlokés hátszögek számításához meg kell határoznunk a vizsgált élpontban a valós forgácsolósebesség, az él-érintő, a homlokfelület-normális és hátfelület-normális vektorokat.

\subsection{A forgácsolósebesség-vektor szá- mítása}

A forgácsolósebességet a vizsgált élpontnak a munkadarab ezzel pillanatnyilag egybeeső pontjához viszonyított relatív sebességeként definiáljuk, és a szerszámhoz kötött koordináta-rendszerben írjuk fel.

A számításhoz a 4. ábrán feltüntetett vektorokat használjuk fel. Megfigyelhető, hogy a munkadarab és a szerszám koordinátarendszerei alaphelyzetben vannak, azaz az $x$ tengelyek egymás meghosszabbításában. Ez a sajátosítás nagymértékben megkönnyíti a számítást. Az általánosságot azzal állítjuk vissza, hogy az élpont helyzetét változtatjuk a szerszámhoz kötött koordináta-rendszerben úgy, hogy a munkadarab-szerszám áthatást jellemző ponthalmazon belül a vizsgált élponthoz az $\left(r_{y}, \theta_{y}, q\right)$ hengerkoordinátákat csatoljuk.

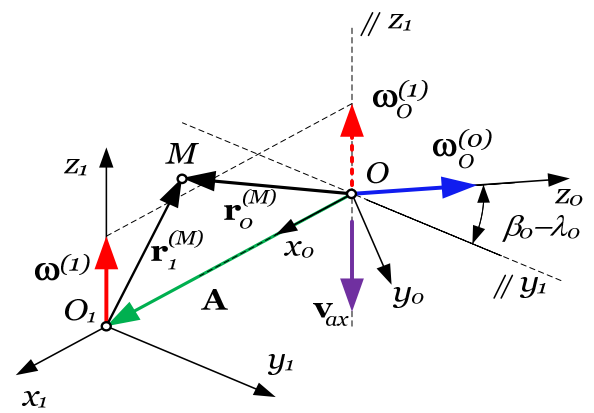

5. ábra. A forgácsolósebesség mint relativ sebességvektor számitása
A forgácsolósebesség-vektor, a [2,5]-ben is ismertetett módszer alapján a következö vektoregyenlettel fejezhető ki:

$$
\mathbf{v}_{0}^{(1,0)}=\left(\boldsymbol{\omega}_{O}^{(0)}-\boldsymbol{\omega}_{O}^{(1)}\right) \times \mathbf{r}_{0}-\mathbf{A} \times \boldsymbol{\omega}_{O}^{(1)}+\mathbf{v}_{a x}
$$

Az elötolásisebesség-vektor a $z_{1}$ tengely irányával megegyező irányú; értékét az $s_{a x}$ tengelyirányú előtolás-paraméter értékéből számítjuk, a $j_{10}=\frac{\omega^{(1)}}{\omega^{(0)}}$ áttételi arány figyelembevételével, amelyet ferde fogazat esetén a fogferdeségi szögnek megfelelően korrigálni kell [4,7]:

$$
v_{a x}=\frac{s_{a x}}{2 \pi} j_{10} \omega^{(0)}
$$

A 4. ábra figyelembevételével és a számítások elvégzése után a relatív forgácsolósebesség-vektor iránya a következö lesz:

$$
\begin{aligned}
\underline{\mathbf{v}}_{0}^{(1,0)} & =\left(\begin{array}{c}
-j_{10}\left(y_{0} \sin \Sigma+z_{0} \cos \Sigma\right) \\
j_{10}\left(x_{0}+A\right) \sin \Sigma+v_{a x} \cos \Sigma-z_{0} \\
j_{10}\left(x_{0}+A\right) \cos \Sigma-v_{a x} \sin \Sigma+y_{0}
\end{array}\right), \\
\Sigma & =\beta_{0}-\lambda_{0}
\end{aligned}
$$

A számítások egyszerüsítése céljából a csigamaró szögsebességét $1 \mathrm{~s}^{-1}$ értéküre vettük. A (13) képletekben szereplő élpontkoordinátákat a hengerkoordináták bevezetésével fejezzük ki. A hengerkoordinátákra azért van szükség, mert könnyebben meg lehet segítségükkel határozni a munkadarab-csigamaró áthatási felületét, mert csak azon belül van értelme a geometria vizsgálatának.

\subsection{Az áthatás vizsgálata}

Áthatásként definiáljuk azt a csigamaróhoz kötött ponthalmazt, amelyben az élpont valós forgácsvételre képes. Mértani szempontból az áthatás egy olyan, a csigamaró tengelyéhez kötött egyenes körhenger-felületdarab, amelynek sugara a vizsgált 
élpontnak a csigamaró tengelyétől mért távolságával egyenlö, határvonala pedig a munkadarab fejhengerével való áthatásgörbe. Az áthatásnak a következökben felhasznált matematikai értelmezése a hengerkoordináták közötti kapcsolat, amely adott $r_{y}$ sugárra, a $\theta=\theta(q)$ alakban írható fel. $\mathrm{Az}$ áthatás határgörbéjét, adott $r_{y}$-ra, az összes lehetséges $q$ értékre számított $\theta^{(\min )}, \theta^{(\max )}$ értékek segítségével írjuk le numerikusan. A számítás elvégzése érdekében a fogaskerék fejhengerének egyenletét átírjuk a szerszám koordináta-rendszerébe, majd a kapott egyenletbe behelyettesítjük az $\left(r_{y}, \theta, q\right)$ hengerkoordinátákat. Eredményként a következö, $\theta, q$ ismeretlenekben és $r_{y}$ paraméterben definiált egyenletet kapjuk:

$$
\left(A-r_{y} \cos \theta\right)^{2}+\left(q-r_{y} \sin \Sigma \sin \theta\right)^{2}-r_{a 1}^{2}=0
$$

Az áthatás fogdőlésszög-, fogszám- és élpontsugár-függő. Grafikus képét, $\beta_{0}=\frac{\pi}{6}$ ra, a 6. ábrán szemléltetjük.

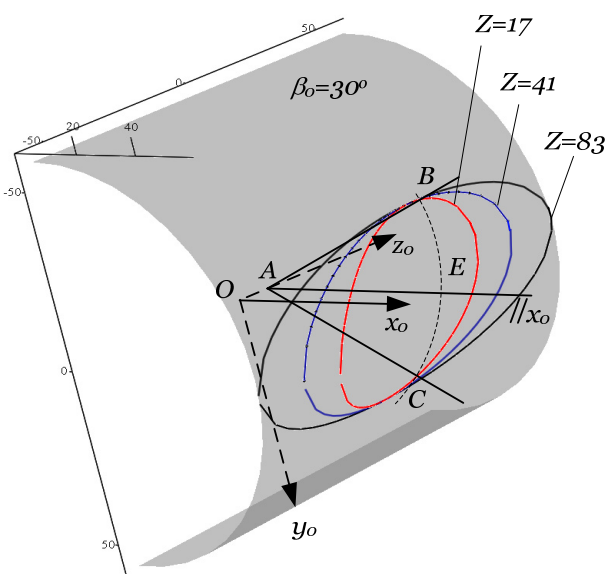

6. ábra. Az áthatás alakjának és határainak változása a megmunkált fogaskerék fogszámának függvényében
Az élpont hengerkoordinátájának adott $q=O A$ értékére a $\theta$ legnagyobb értéke a $(C A E)$, legkisebb értéke pedig a (BAE) szög értékével egyenlő. Értelemszerúen utóbbi az $x$ tengelyhez viszonyított helyzete miatt negatív. A $q$ paraméter szélső értékeinek a határgörbe zártságából adódó számítási feltétele a $\theta$ szélsőértékek közötti elhanyagolhatóan kis különbség.

\subsection{A homlok- és hátfelület-normális, illetve az él-érintővektorok szá- mítása}

Az él $\tau$ érintővektorának koordinátáit a (8) egyenletek deriválásával álltjuk elő.

A homlokfelület normálvektorát a $\boldsymbol{\tau}$ érintővektor és a homlokfelületnek a vizsgált élponton áthaladó egyenesére illesztett vektor vektoriális szorzataként állítjuk elő. Az említett egyenes merőleges a forgástengelyre, tehát a ráillesztett vektor koordinátái értelemszerüen $\quad \underline{\mathbf{u}}_{0}^{T}=\left(\begin{array}{lll}x_{0} & y_{0} & 0\end{array}\right) . \quad$ Ennek alapján felírható, hogy

$$
\underline{\mathbf{n}}_{\gamma}=\left(\begin{array}{ccc}
0 & -\tau_{z} & \tau_{y} \\
\tau_{z} & 0 & -\tau_{x} \\
-\tau_{y} & \tau_{x} & 0
\end{array}\right) \underline{\mathbf{u}}_{0}^{T}
$$

A hátfelület $\mathbf{n}_{\alpha}$ normálvektorát szintén az él érintővektora és a hátfelületnek a vizsgált élponton áthaladó kúpos csavarvonal- w érintővektora vektoriális szorzataként állítjuk elö. A számításokat terjedelmük miatt, mellőzzük, ezek részletesen a [4]-ben találhatók.

A geometria számításához szükséges vektorokat az $x_{0} y_{0} z_{0}$ koordinátarendszerhez kötött, (8) egyenletekkel leírt él pontjához kötöttek. Ahhoz, hogy megvizsgáljuk, milyen lesz a geometria a vizsgált élpontban, ha ez a $(\theta, q)$ paraméterpár által kijelölt helyzetbe kerül, koordinátatranszformációt kell alkalmaznunk. Ennek kiszámításához a $\varphi_{1}$ paraméter adott értékének megfelelő $M$ élpont $\left(x_{0}^{(M)}, y_{0}^{(M)}, z_{0}^{(M)}\right)$ 
kiszámított koordinátákhoz hozzárendeljük az $\left(r^{(M)} \theta^{(M)}, q^{(M)}\right)$ hengerkoordinátákat. A $(\theta, q)$ paraméterpár a vizsgált pontot olyan helyzetbe rendeli, az áthatáson belül, amelybe a csigamaró $z$ tengelye mentén való elcsúsztatással és körülötte történő elforgatással hozható. Értelemszerüen a transzformáció mátrixa a következő:

$\mathbf{M}(\theta, q)=\left(\begin{array}{cccc}\cos \Delta \theta & -\sin \Delta \theta & 0 & 0 \\ \sin \Delta \theta & \cos \Delta \theta & 0 & 0 \\ 0 & 0 & 1 & q-q^{(M)} \\ 0 & 0 & 0 & 1\end{array}\right)$, $\Delta \theta=\theta-\theta^{(M)}$

A geometria felírásához a $\mathbf{v}_{0}^{(1,0)}, \boldsymbol{\tau}, \mathbf{n}_{\gamma}, \mathbf{n}_{\alpha}$ vektorok koordinátáit a (16) transzformációnk megfelelően átírjuk. Ezek után alkalmazni lehet a [4]-ben részletezett geometria-számítási módszert. A vektoriális modell használatával kiszámítjuk a müködő homlok- és hátszöget. A továbbiakban az egybekezdésű, $\quad \lambda_{0}=2^{\circ} 30^{\prime} \quad$ csavarvonaldőlésszögű csigamaró működő élgeometriáját vizsgáltuk $Z \in[17,101]$ fogtartományban és $\beta_{0} \in\left[0^{\circ}, 45^{\circ}\right]$ fogferdeségi szögtartományban. A $q$ paraméter értékei meghatározzák a vizsgált él helyzetét a legördülés szempontjából. Ha a csigamaró jobbos, és jobbra dôlt fogazatot munkál meg, akkor a fogaskerék forgásiránya szerint a $q$ negatív értékeinek a kigördülési zóna, míg a pozitív értékeinek a begördülési zóna felel. meg. A legnagyobb áthatás zónája a $q$ paraméter nulla közeli értékére keletkezik. A vizsgálat során megállapítottuk, hogy sem a müködő homlokszög, sem a müködő hátszög nem változik lényegesen az él lokációja szempontjából; természetesen a legnagyobb áthatás a központi zónában található. Ezért a továbbiakban a geometria változását itt fogjuk szemléltetni. A szögváltozás grafikonja- inak abszcisszáin a csigamaró forgásából következő szöghelyzet-paraméter, az ordinátákon pedig a vizsgált szög van feltüntetve, fokokban.

\section{A múködő homlokszög változása}

\subsection{Az élpont helyzetének befolyása}

A müködő homlokszög változása az élpont helyzete szerint a 7. és 8. ábrákon látható. $\mathrm{Az} R_{a}, R_{0}, R_{i}$ értékek rendre a csigamaró fej-, osztó-, illetve belső hengeri élpontját jelölik ki. A változásokat a $Z=59$ fogszámra és a $\beta_{0}=22^{\circ} 30^{\prime}$ fogferdeségi szögre tanulmányoztuk.

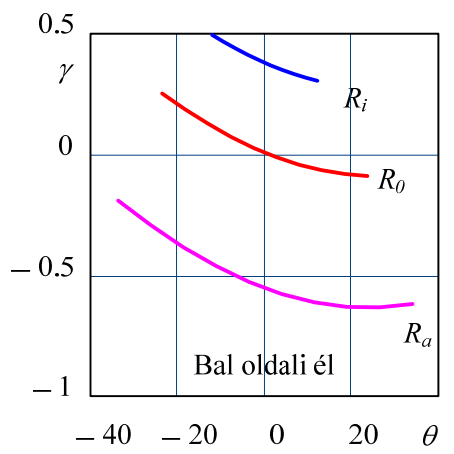

7. ábra. A müködö homlokszög változása a bal oldali élen

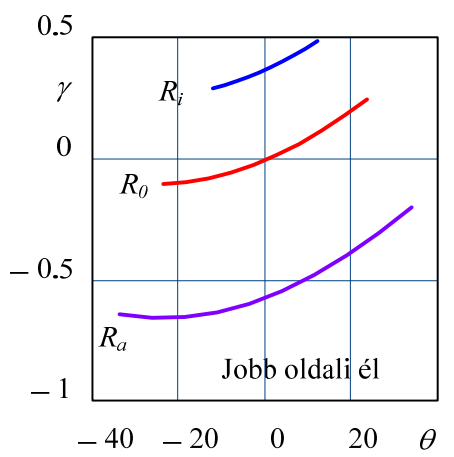

8. ábra. A müködö homlokszög változása a jobb oldali élen 
A 7. és 8. ábra együttes vizsgálatából megállapítható, hogy a müködő homlokszög folyamatosan változik a csigamaró fogának $\theta$ helyzetparamétere szerint. A változás mértéke gyakorlatilag elfogadható. Továbbá észrevehető, hogy a bal oldali élen a tendencia csökkenő, míg a jobb oldali élen növekvő. Az élpont helyzete szerint kijelenthetö, hogy minél távolabb található a csigamaró tengelyétől, annál kisebb értékek között változik. A változás intervalluma azért nagyobb, mert a nagy szerszámátmérőn nagyobb terjedelmü áthatás jön létre.

\subsection{A fogferdeségi szög befolyása}

A fogferdeségi szög befolyását a müködő homlokszögre $\beta_{0}=0^{\circ} ; 22^{\circ} 30^{\prime} ; 45^{\circ}$ értékekre vizsgáltuk, $Z=59$ fogszámra és az él $R_{0}$ sugarú osztóhengeri pontjára. A változások a 9. és 10. ábrákon figyelhetők meg.

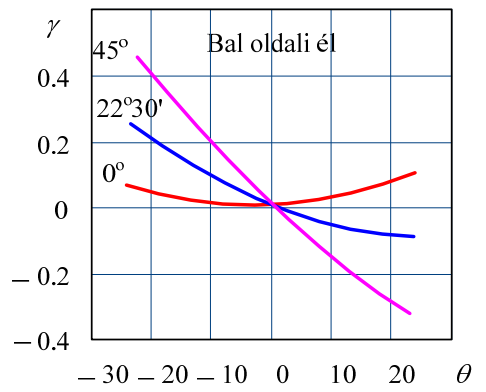

9. ábra. A müködési homlokszög változása a fogferdeségi szög függvényében a bal oldali élen

Az ábrák vizsgálata alapján megállapíthatjuk, hogy a homlokszögváltozás előbb kimutatott tendenciája megmarad. Az egyenes fogú fogaskerekek lefejtésekor a változás elhanyagolható, különben annál nagyobb, minél nagyobb a fogferdeség.

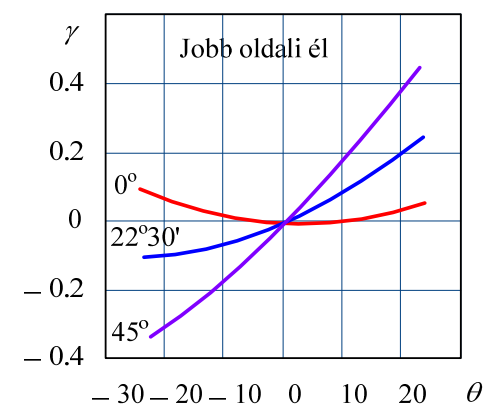

10. ábra. A homlokszög változása a fogferdeségi szög függvényében a jobb oldali élen

\subsection{A fogszám befolyása}

A fogszám befolyását a homlokszögre a $Z=17 ; 59 ; 101$ fogszámokra vizsgáltuk az osztóhengeri élpontra és $\beta_{0}=22^{\circ} 30^{\prime}$ fogferdeségi szögre. A változások a 11. és 12. ábrákon láthatók.

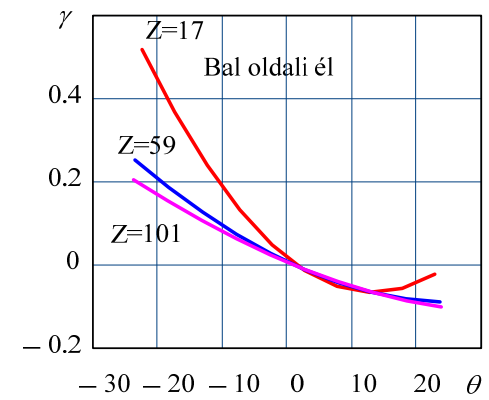

11. ábra. A homlokszög változása a fogszám függvényében, a bal oldali élen

Az ábrák alapján kijelenthető, hogy a fogszám befolyása akkor lényeges, amikor az áthatási zóna alakját érdemben befolyásolja. Észrevehetö, hogy 59 fog felett a fogszám befolyása a homlokszögváltozásra gyakorlatilag nulla. 


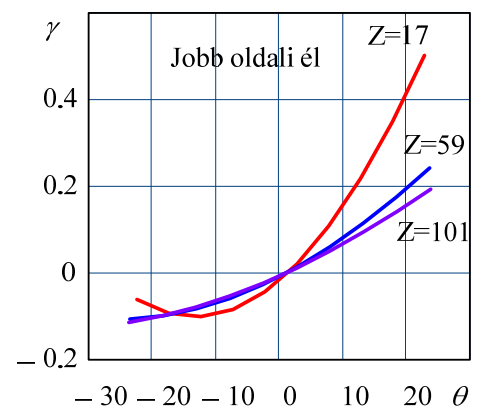

12. ábra. A homlokszög változása a fogszám függvényében a jobb oldali élen

\section{A működő hátszög változása}

A müködő hátszög változását ugyanazon körülmények között vizsgáltuk, mint az elöbbiekben bemutatott homlokszögváltozást.

\subsection{Az élpont helyzetének befolyása}

$\mathrm{Az}$ élpont helyzetének befolyását a $\mathbf{1 3}$. és 14. ábrákon tüntettük fel.

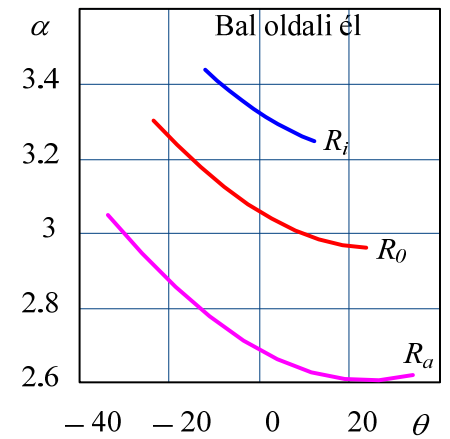

13. ábra. A hátszög változása a bal oldali élen

Az ábrák vizsgálatából megállapítható, hogy a múködö oldalhomlokszögek változása a konstruktív értékektől [1, 4] alig egyetlen foknyi intervallumban tér el. A változás mindkét fogoldalon ugyanolyan irányú, vagyis a szerszám forgási szögének növekedésével csökken. A csökkenés annál

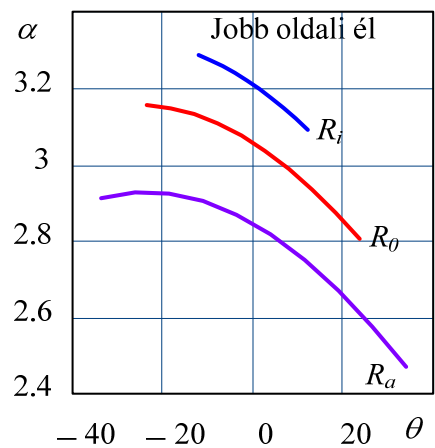

14. ábra. A hátszög változása a jobb oldali élen

nagyobb mértékü, minél nagyobb az élpont sugara. Pusztán matematikai érdekességként említjük meg, hogy a bal oldali élen domború, a jobb oldalin pedig homorú.

\subsection{A fogferdeségi szög befolyása}

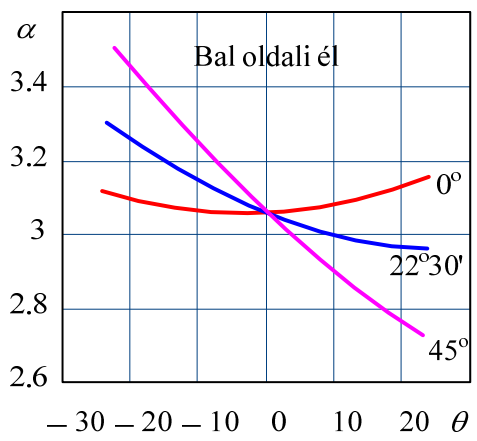

15. ábra. A hátszög változása a fogferdeségi szög függvényében a bal oldali élen

A lefejtett fogazat fogferdeségi szögének növekedésével a müködő hátszögek variációs intervalluma megnövekedik, ahogyan azt a 15. és 16. ábrán szemléltetett grafikonokból leolvashatjuk. Általánosan kijelenthetjük, hogy a csökkenő tendencia megmarad. Megfigyelhetö, hogy a bal oldali élen a maximális értékek nagyobbak, a jobb oldali élen pedig a minimális értékek kisebbek. 


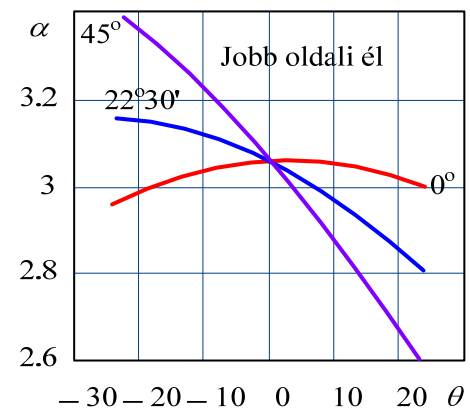

16. ábra. A hátszög változása a fogferdeségi szög függvényében a jobb oldali élen

\subsection{A fogszám befolyása}

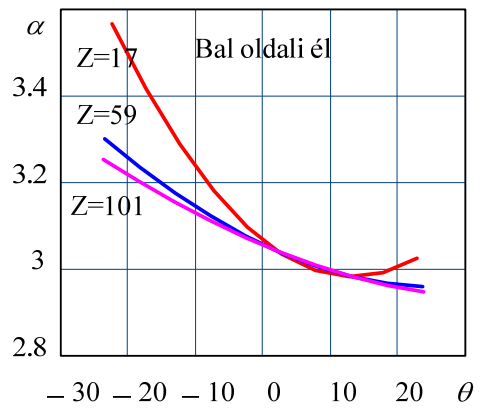

17. ábra. A hátszög változása a fogszám függvényében, a bal oldali élen

A fogszám befolyását a müködő hátszögre a 17. és 18 ábrákon szemléltettük. Észre lehet venni, hogy minél nagyobb a fogazott kerék fogszáma, annál kisebb a hátszög változása. Akár a homlokszög esetében, $Z=59$ fog felett a fogszám befolyása elhanyagolható.

\section{Következtetések}

A 7-16. ábrák összehasonlító együttes vizsgálata alapján kijelenthetjük, hogy a csigamaró müködő élszögeinek változása a vizsgált paraméterek függvényében $1^{\circ}$-nál kisebb. Részletes gyakorlati kutatások igazolták [8], hogy föként a müködő oldalhátszög jelentősen befolyásolja a for-

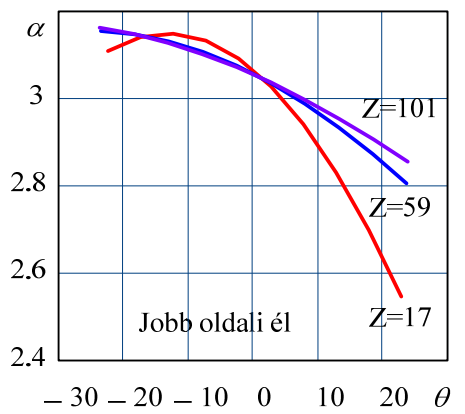

18. ábra. A hátszög változása a fogszám függvényében a jobb oldali élen

gácsképződés körülményeit, a szerszám kopását és a megmunkálás pontosságát.

A legnagyobb változások a fejköri élponton (tehát a lekerekítési szakaszon) alacsony fogszámú és nagy fogferdeségü kerekek megmunkálásakor lépnek fel.

\section{Szakirodalmi hivatkozások}

[1] Radzevich, P. S.: Dudley's Handbook of Practical Gear Design. CRC-Press, London, 2016, 368-379.

[2] Litvin F.L.: A fogaskerékkapcsolás elmélete, Müszaki Könyvkiadó, Budapest, 1972, 187190 oldal.

[3] Hollanda D.: Bazele așchierii și generării suprafețelor, „Petru Maior” Egyetem, Marosvásárhely, 1994.

[4] Máté M.: Hengeres fogaskerekek gyártószerszámai, Erdélyi Múzeum-Egyesület, Kolozsvár, 2016, 187-206 oldal.

[5] Dudás, I. The Theory and Practice of Gear Worm Drives, Penton Press, London, 2000.

[6] Radzevich, P. S.: Gear Cutting Tools. Fundamentals of design and computation, CRCPress, London, 2010.

[7] Gyenge Cs.: Lefejtömarók oldalhátszögének pontos meghatározása és optimálása, Gép, 48. évf. (1996), 10 sz, 38-40 oldal.

[8] Gyenge Cs.: Contribuții asupra îmbunătățirii preciziei frezelor-melc pentru executarea angrenajului melcat duplex. Doktori értekezés, Kolozsvári Müszaki Egyetem, 1979. 69-100. 